\title{
Balancing wood market demand and common property rights: a case study of a community in the Italian Alps
}

Alessandro ${ }^{1}$ Paletto, Isabella ${ }^{2}$ De Meo, Maria Giulia ${ }^{3}$ Cantiani, Dario ${ }^{1}$ Cocciardi,

${ }^{1}$ Consiglio per la Ricerca e la sperimentazione in Agricoltura - Forest Monitoring and Planning Research Unit (CRA-MPF), Villazzano of Trento (Italy)

${ }^{2}$ Consiglio per la Ricerca e la sperimentazione in Agricoltura - Agrobiology and Pedology Centre (CRA-ABP), Florence (Italy)

${ }^{3}$ Department of Civil and Environmental Engineering, University of Trento, Trento (Italy)

Key-words: common property rights, firewood, biomass-energy, conflicts, Trentino (Italy).

\begin{abstract}
Dating back to the Middle Ages, when alpine village communities managed common forests and pastures, common property rights have a long tradition in the Italian Alps. On these common properties and in accordance with rules aimed at regulating and organising the collective use of resources, shareholders have the right of common use of the land. Nowadays, alpine communities are characterised by a historical tradition in the common management of natural resources, a selforganised governance system, high social capital, and a strong collective identity. At present, as many mountainous areas still rely heavily on firewood for the heating of homes and the production of hot water, the right to gather firewood and timber from common forests (bote right) is the most important common property right.

In the last few decades, renewable bio-energy production based on forest woody biomass has undergone significant development. According to recent EU policies, there is likely to be further growth in the use of wood for energy production.

In Italy, in communities where bote rights still have economic, social, and cultural relevance, the possibility exists of conflicts between decision makers and community members around the use of firewood. This paper focuses on this issue by presenting a case study located in the north-east Italian Alps. The study area is the Municipality of Baselga di Pinè in the Province of Trento, characterised by a historical tradition of common property management. A capacity for modifying and adapting to social, economic, and cultural change makes this alpine community a model of efficiency and good governance. Common forests are administered by organisations and their representatives. Members of the community have bote rights and grazing rights, and firewood represents an important source for domestic heating.

In order to analyse potential conflicts between decision makers and community members, a semistructured questionnaire was submitted to the administrators of the common forests and to the shareholders. In order to develop different scenarios of wood use, data deriving from the questionnaires were analysed and combined with data regarding potential wood for energy production. Information derived from such scenarios is important as it helps managers and decision makers to identify on-going trends in firewood demand and can be efficiently integrated into the strategies of the management and government of natural resources.
\end{abstract}

\section{INTRODUCTION}

Italy has a long tradition of collective forms of ownership and management of its natural resources, which are comprised mainly of forests and pastures in mountainous regions.

As a result of: i) the large variety of environments, physical and geographical - the country's territory extends from the Alpine Chain to the area of the Mediterranean - and ii) the historical events that influenced the country in various geographical locations, the common properties display a peculiarity that is reflected, too, in the various names attributed to the institutions that govern 
them, namely, ("Regole", "Comunità", "Consortele", "Vicinie" of the Alpine chain; "Università Agrarie", "Comunanze" e "Participanze" of the Appennine mountains).

Historically, natural resources have always played a fundamental role in the survivial of communities living in mountain territories, territories characterised by complex ecosystems and, particularly in the Alpine mountain, by an environment that is both hostile and physically fragile. In such an environment, human activities have always been directed, on one hand, towards procuring enough raw materials and producing enough food to satisfy the needs of the local community, and on the other, towards building dwellings suitable for human habitation, particularly insofar as it relates to the need to defend the village from natural disasters (Messerli, 1989; Netting, 1981). The mountain habitat imposed diversified production strategies and appropriate forms of ownership and management. Lands situated on high ground, where grazing and gathering prevailed, were generally common property and, in some cases, collectively managed; meadows and fields, situated on lower lying ground and privately owned, were individually managed (Viazzo, 1989).

Common rights (usi civici in Italian) include the right to: gather firewood and cut timber (bote right), graze cattle and sheep, collect grass- and leaf litter for cattle, gather fruits and mushrooms, hunt, fish, mine, and design water-use regimes.

Sustainable resource management particularly well adapted to specific local conditions has been made possible through various original, autonomous forms of organisation and government of the common lands. A determining factor in the conservation of common goods is that all the components of the community regard themselves as co-proprietors in that they are directly involved in ensuring that resources are correctly used and rules, imposed by the community itself, duly respected.

The numerous statutes dating back to the Middle Ages and which regulated the community's social and economic life attest to the existence of such rules (Kissingl-Näf et al., 2002; Merlo, 1995; Scotti and Cadoni, 2007), even though historical research reveals that the origins of these institutions can be traced back to ancient settlements that pre-date the Roman Conquest (Sereni, 1955).

It is difficult to draw a complete picture of the situation regarding common properties in Italy as: i) no national law exists in this regard, resulting in the institutions that govern such common properties not being legally recognised, and ii) no precise knowledge exists of the land surface in question.

Research conducted in 1947 by the National Institute of Agricultural Economy (I.N.E.A., 1947) estimated that the collective lands covered an area of 3,085,000 ha, equal to ten percent of the entire territory of the country. However, it was only in 2011 that, for the first time in the history of Italy, the National Institute of Statistics (I.S.T.A.T.), with the assistance of the National Council for Collective Properties, was able systematically to retrieve from the agricultural census data relating to collective properties. Although initial results indicate that collective ownership is both widespread and variegated, and involves an area of at least 1,325,000 ha (data yet to be published), these results are incomplete as they refer to only some of the regions in Italy.

Long considered an anachronistic remnant of days gone by, collective properties have nevertheless survived a succession of blows inflicted by Illuminism, in the first instance, and $19^{\text {th }}$ century Positivism, in the second. It is a testament to their resilience that they patently resisted, albeit with many ups and downs, the profound socio-economic changes that characterised the $20^{\text {th }}$ century, becoming "successful" institutions, institutions that fulfil the design principles of Elinor Ostrom (1990).

Today, however, even the most active and vital of institutions, many of which can be found in certain sectors of the Alpine Arc, are showing signs of crisis.

The territory's stakeholder network has been interrupted as a result of changing generations, factors relating to emigration and, more recently, to immigration, and to the phenomenon of commuting, often widespread. 
These communities no longer possess a common cultural background; in the past, the isolation of the valleys favoured the development of self-sufficient systems of supply-and-demand, characterised by a heritage of common knowledge, customs, and values (Cole and Wolf, 1974; Wolf, 1962).

These problems, of a social nature, are accompanied by other, equally significant changes of an economic nature, and alternative uses of forest and grazing resources now run alongside traditional uses. Such alternative use, however, connected as it is to the development of tourism, often predominates.

In many places, the abandonment of farming, an activity, until recently, typical of the Alpine mountain, has resulted in the wood encroaching upon open areas. This, in turn, has resulted in the loss, virtually irreversible, of many grassland ecosystems and, simultaneously, in a drastic transformation of the landscape, with negative repercussions also on the tourism industry.

Also the forestry sector, which has a tradition of robust resistance, is in crisis; an increase in the costs of utilisation of wood at times creates severe economic hardship for those local industries whose businesses revolve around the processing of wood. There are new economic interests that have arisen meanwhile, mainly in relation to the use of wood as a renewable source of energy, a sector that, in Italy, has seen a significant increase in recent years, in terms of investment, turnover, employment, and power. National and regional policies are increasingly oriented towards encouraging the development of the forest-wood-energy chain. As provided for by Directive 2009/28/EC on the promotion of the use of energy from renewable sources (20-20-20 targets), it is conceivable that, in the future, there will be further growth in the use of wood-based biomass fuels.

In communities where bote rights still have economic, social, and cultural relevance, potential conflicts between decision makers and community members around the use of firewood cannot be ruled out.

Our research, carried out by means of a case study, focuses on the analysis of these potential conflicts and attempts to identify ways in which they may be handled while simultaneously taking advantage of the opportunities that may arise from the recent socio-economic changes.

\section{METHODS}

\section{Study area}

The study area is the Municipality of Baselga di Pinè (latitude $46^{\circ} 8^{\prime} 0^{\prime \prime} \mathrm{N}$, longitude $11^{\circ} 14^{\prime} 0^{\prime \prime} \mathrm{E}$ ), located in the North East sector of the Italian Alps, in the Province of Trento (Italy). The province, characterised by an ancient tradition of common property management, is home to many different, important self-organised institutions responsible for the management of the common lands, such as the Regole Spinale-Manez, the Consortele of the Rabbi valley, the Amministrazioni Separate per gli Usi Civici (Separated Administrations for Common Rights), and the Magnifica Comunità di Fiemme.

To this day, common property in the Province of Trento has maintained a prominent socioeconomic role. Recently, a law of the province (Provincial Law $n^{\circ} 6,2005$ ), which reorganises the subject of common properties and common rights, acknowledged the importance of the common property institutions for the conservation of the alpine environment, its traditional landscape, and its cultural heritage. Common property affects about 337,000 ha (fifty-five percent of the entire territory of the province). Of these, 75,000 ha are administered by the Amministrazioni Separate per gli Usi Civici or ASUC (ninety-eight in the Province of Trento). The origin of these institutions is quite recent as they were put in place following a national law in 1927 and a provincial law in1952, both aimed at revising the common property and common rights situation. However, common properties managed by the ASUC generally have a long history, their origin dating back to the Middle Ages or indeed prior to that. The ASUC's remit is to manage the common property by means of the autonomous administration of the assets, in favour solely of those inhabitants, the so- 
called householders, who live in the hamlet where these assets have been registered in the official book of records. The functioning of each ASUC is based on its own specific statute.

The Municipality of Baselga di Pinè was chosen for our research for the reason that it represents well the way common properties are managed in the Province of Trento. There are nine ASUC present, each of them corresponding to one of the nine hamlets that constitute the municipality. Each hamlet maintains its identity as an autonomous village, mainly due to its socio-territorial organisation, characterised by spatial- and social cohesion. The householders elect from amongst themselves five representatives, the steering committee, which rules for five years. The committee, in turn, elects a president. In the ASUC of Baselga di Pinè, people become part of the community (shareholders) after residing in the village for ten years.

As in the other ASUC of the Province of Trento, today the bote right is considered by the population the most important common right: as firewood still represents an important source for the heating of homes, a "share" of firewood and, in some cases, a certain amount of timber is allotted each year to each householder, the quantity being assigned on the basis of a forest management plan. After satisfying the bote rights, the remaining wood is sold on the market. The profits are used to pay the forest guard and the secretarial staff, taxes and administration expenses, and invested in services or public works for the benefit of the community (hamlet houses, hospitals, playgrounds for children, and so on).

From an environmental point of view, the Municipality of Baselga di Pinè covers an area of approximately forty square kilometers, of which eighty percent is forest. The main forest types consist of pure stands of Norway spruce (Picea abies L.), or mixed spruce, beech (Fagus sylvatica L.), and silver fir (Abies alba Mill.) stands, or Scots pine (Pinus sylvestris L) stands, currently in ecological succession with broadleaves. Limited stands of larch (Larix decidua Mill.) and Swiss stone pine (Pinus cembra L.) are also present. Insofar as ownership is concerned, most of the forests and pastures are common lands, while private property is rather limited.

Baselga di Pinè has a population of 4,856 permanent residents, who still have a very strong bond with the territory and the local traditions, and who are greatly concerned with the problems of the area's future development. In particular, people deplore the loss of pastures and meadows, caused by the decline in livestock farming (De Meo et al., 2012).

The common roots of this territory can be found in the remotest of times. The first official document is the Rule of the "Magnifica Comunità di Pinè", which was underwritten by the PrinceBishop of Trento, the feudal lord of the region, in 1262 (Vigna, 1989). The Rule gave a written form to the uses and customs that had always regulated community life and sanctioned their right to self-organisation and self-government. In subsequent centuries, although the Rule was modified to adapt to the socio-economic changes taking place, it consistently guaranteed the community's autonomy. Numerous attempts by various successive conquerors to expropriate the rights of the people were met by strong opposition from the local population. The region was finally annexed to the Kingdom of Italy in the $19^{\text {th }}$ century.

From an economic point of view, the area's main source of income is derived from its tourism sector; as many as 65,000 tourists visit the area during the summer. The cultivation of small fruits also contributes to the economic development of this rural area. Porphyry mining and processing, while representing another important sector in the local economy, also raises a pressing environmental issue as regards its impact on the landscape and its ecosystems.

The forestry sector and consequently the timber industry has been in decline since the middle of the $19^{\text {th }}$ century. The intensity of grazing also gradually decreased from the 1970s onwards and large tracts of formerly pastureland were abandoned, to be colonised by shrubs and new forests (Sitzia, 2009).

Survey on perception relating to bote right and wood bio-energy production.

The sample of shareholders considered in this research is represented by the presidents of the nine ASUC and by a subset of householders. Concerning the householders, the sampling is proportionally stratified for age and place of birth (geographical provenance). In fact these two 
variables are likely to exert a strong influence on the level of satisfaction about regarding the bote right and perceptions regarding the alternative use of woody biomass for energy production. The final sample size included thirty-four householders and the nine presidents, a total of forty-three shareholders (Cocciardi, 2011).

A semi-structured questionnaire suitable for a face-to-face interview was developed to collect data and to work as an interview guide. The questionnaire comprises twenty-seven close-ended questions and eight open-ended questions. Close-ended questions - in which respondents have to choose from a list of preset responses - were chosen in order to keep the structure simple. Moreover, responses to close-ended questions are easily analysed, allowing both quantitative and qualitative examination. The open-ended questions were devised for the purpose of encouraging people to make their opinions clear and to discuss those topics of major interest to them. This made it possible to improve the analysis and to gain a more in-depth understanding of the results.

The questionnaire addressed the need for a better understanding of how the tradition of common property is rooted in the community, and to investigate the potential conflicts between decision makers (administrators of the municipality or the Province of Trento) and community members. In particular, the questionnaire is designed to investigate community members' perception with respect to bote right and forest woody biomass use for energy production.

The questionnaire is organised into thematic sections. The themes investigated are: i) satisfaction relating to bote right and to the amount of assigned firewood; ii) opinions regarding the usefulness of wood for renewable bio-energy production; iii) the system of domestic heating and its characteristics; and iv) experience-based opinions regarding the availability of wood from local forests, and its destination. Thematic section i) referred to above contains seven questions, which concern the objective of the paper.

Regarding data acquisition, the interviews were conducted from May 2010 to January 2011. Presidents were interviewed at the administration offices of the ASUC. Householders were contacted by telephone to check their willingness to be interviewed and to fix the day of the meeting. Interviews were conducted at the respondents' place of work, in their own home, or in a public place. Questions and possible alternative answers were read by interviewer and interviewee together. For each question, besides ticking the given answer, a discussion and an exchange of information took place, the aim being to collect explanations for responses and to discuss with interviewees various related aspects. It was assumed that discussion would help to interpret the quantitative results. Such discussion would, in fact, prove helpful as interviewees sometimes had difficulty in understanding the significance of some words and concepts.

The "Don't know" answer was usually available so that the respondent was not forced to give an answer that did not fully reflect his or her views.

In some cases, a blank space was left beside the close-ended questions in order to provide the respondent with an opportunity to give an explanation. Similarly, at the end of the questionnaire, room was left for comments, suggestions, or other ideas regarding the various issues.

The structure and comprehensibility of the questions were checked, and various revisions undertaken to make the questionnaire easily accessible to everybody.

GIS model to evaluate potential woody biomass

The potential forest woody biomass in the Baselga di Pinè Municipality was assessed via a forecasting model called the Biomasfor model (Sacchelli et al., 2011). This model, based on Geographic Information Systems (GIS), computes a multi-step analysis that permits the quantification of the biomass obtainable from forest harvesting residues in a sustainable way from both an ecological and technical-economic point of view. The assessment is carried out based on aspects of multifunctionality and their potential relationship with biomass energy production. The forest functions considered in the model are: soil and water protection, biodiversity and habitat conservation, fire risk prevention, tourist and recreational function, and economic evaluation related to timber and bio-energy processing. The quantity of biomass estimated by the model includes the residues from forest harvesting (top, branches, twigs), but does not take into account dead trees. 


\section{Data analysis}

The questionnaires are used to collect data concerning the shareholders' level of satisfaction with respect to the annual amount of firewood assigned by the ASUC (bote rights). Furthermore, the information obtained through interviews shows shareholders' need to integrate their quantity of firewood with the main sources of wood supply.

Data relating to the quantity of firewood assigned per shareholder and per ASUC are obtained from the forest statistics of the Province of Trento.

The Biomasfor model estimates the forest woody biomass potential in the Municipality of Baselga di Pinè.

The aggregated analysis of the abovementioned data and information allows for the definition of three main scenarios of wood use and management.

The responses received to the open-ended questions, together with the notes relating to interview discussions, formed the qualitative part of the data. This information is studied to find support and logical interpretations for the quantitative results.

\section{RESULTS}

According to the forest statistics of the Province of Trento, the firewood assigned to the shareholders is around 831 tons per year (average value for the period 2008 - 2012, Fig.1). Observing Table 1, it can be noted that the values range from 35.1 tons per year (the ASUC of Ricaldo) to 192.5 tons per year (the ASUC of Miola), depending on the amount of firewood collected from the forests of the Baselga Municipality, which amount varies with land use distribution and the number of shareholders. Furthermore, the quantity of firewood assigned to the shareholders depends on forest management plan prescriptions and on external events (such as a variation in the quantity of firewood available following natural disasters). Figure 1 shows the trend of the firewood assigned to the shareholders and highlights the variations from year to year.

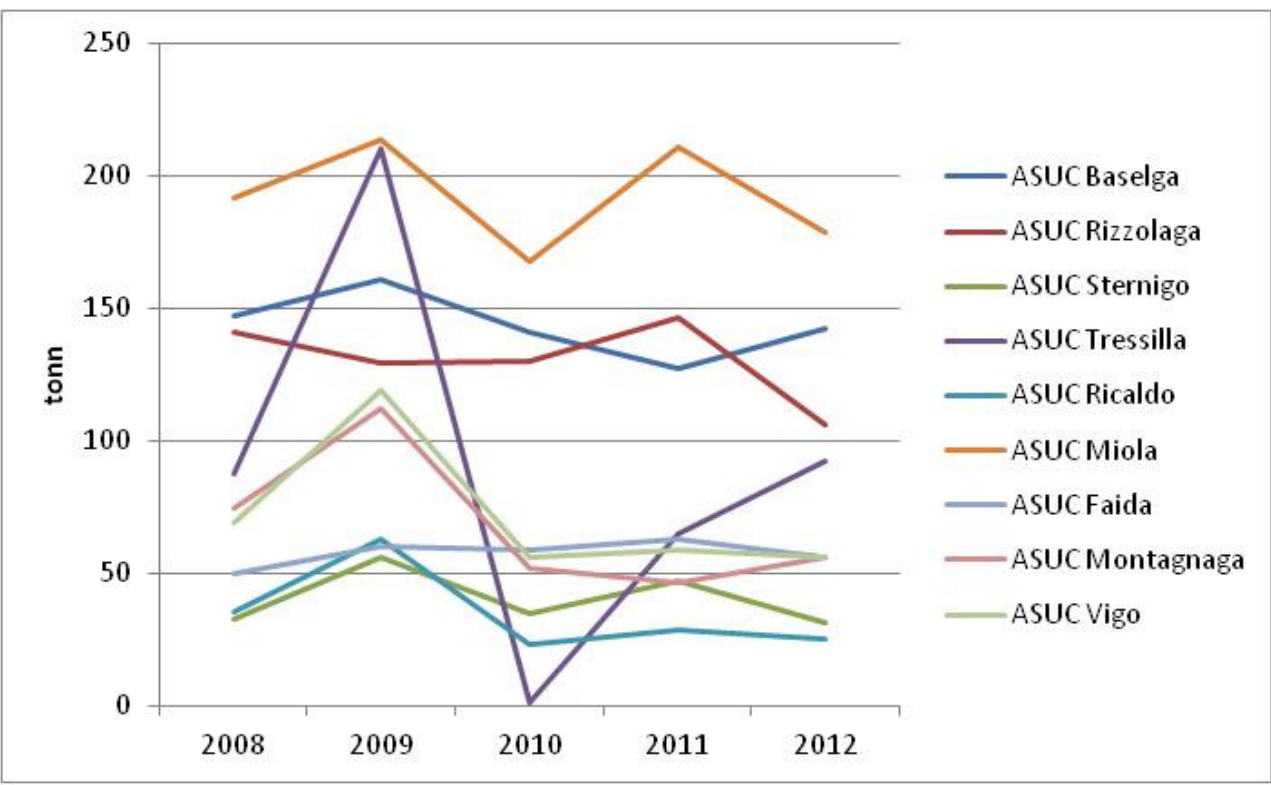

Figure 1. Trend of firewood assigned in the nine ASUC of the Municipality of Baselga. Period: 2008 to 2012. Source: Forest Statistics of the Province of Trento.

Taking into consideration the average annual quantity of firewood assigned per shareholder (Table 1), it can be observed that in six ASUC (Miola, Ricaldo, Rizzolaga, Sternigo, Tressilla, and Vigo) the quantity is 1.4 tons per shareholder, and in the other three (Baselga, Faida and Montagnaga) 1.05 tons per shareholder. The average value in the study area is 1.28 tons per shareholder. 


\begin{tabular}{|l|r|r|r|r|r|}
\hline \multicolumn{1}{|c|}{ ASUC } & \multicolumn{1}{|c|}{$\begin{array}{c}\text { Number of } \\
\text { shareholders }\end{array}$} & \multicolumn{1}{|c|}{$\begin{array}{c}\text { Forest area } \\
\text { (ha) }\end{array}$} & $\begin{array}{c}\text { Total } \\
\text { firewood } \\
\text { assigned } \\
\text { (t) }\end{array}$ & $\begin{array}{c}\text { Average } \\
\text { firewood per } \\
\text { shareholder } \\
\text { (t) }\end{array}$ & $\begin{array}{c}\text { Number of } \\
\text { shareholders } \\
\text { who received } \\
\text { firewood }\end{array}$ \\
\hline Baselga & 395 & 179 & 143.6 & 1.05 & 135 \\
\hline Faida & 131 & 278 & 57.5 & 1.05 & 41 \\
\hline Miola & 459 & 396 & 192.5 & 1.4 & 138 \\
\hline Montagnaga & 250 & 123 & 68.0 & 1.05 & 25 \\
\hline Ricaldo & 95 & 83 & 35.1 & 1.4 & 124 \\
\hline Rizzolaga & 229 & 192 & 130.6 & 1.4 & 29 \\
\hline Sternigo & 108 & 116 & 40.5 & 1.4 & 87 \\
\hline Tressilla, San & 228 & 162 & 91.3 & 1.4 & 51 \\
Mauro & 104 & 142 & 71.8 & 1.4 & $\mathbf{6 8 1}$ \\
\hline Vigo & $\mathbf{1 , 9 9 9}$ & $\mathbf{1 , 6 7 1}$ & $\mathbf{8 3 1 . 0}$ & $\mathbf{1 . 2 8}$ & \\
\hline Total & & & & & \\
\hline
\end{tabular}

Table 1. Number of shareholders, forest surfaces, and firewood assigned in the nine ASUC.

Regarding the percentage of shareholders that have an annual portion of firewood, it can be observed that a third of the shareholders received a share (average value for the period 2008 -2012). In particular, this percentage varies: in the case of the Rizzolaga ASUC, firewood is provided to fifty-four percent of shareholders; in the case of the Montagnaga ASUC, firewood is provided to only twenty percent of them. Furthermore, the provincial statistics show that those shareholders not interested in receiving firewood number around twenty-one percent of the total. Consequently, it is possible to subdivide the shareholders into three categories: shareholders that received a share (34.5\%), shareholders not interested in receiving firewood (20.9\%), and shareholders interested in receiving firewood but who had not received a share $(44.6 \%)$.

According to the information collected via the survey, data related to shareholders' level of satisfaction with respect to the amount of assigned firewood are analysed.

Of the questions referred to in "Satisfaction relating to bote right and to the amount of assigned firewood", the inquiry "Did the quantity of assigned firewood satisfy your need?" was selected.

The question investigates whether the interviewees were satisfied with the portion of firewood assigned. If the answer is negative, then the question "How did you integrate your energy needs?" examines the main sources of supply.

The analysis of the responses to these questions shows that $71.1 \%$ of the respondents who received firewood declared that the amount did not satisfy their need. The main sources of supply (Fig.2) are, firstly, the shares of other shareholders or private forests (seventy percent) and, secondly, buying from local traders (twenty-two percent).

The question "Which was the quantity of additional firewood?" investigated the amount of supply. Responses to this question allowed us to establish that an average quantity of 3.7 tons of firewood per shareholder was needed to integrate into the share assigned.

Consequently, we can estimate that the total biomass energy requirement is around five tons per shareholder, corresponding to 4,658 tons in the Baselga Municipality. 


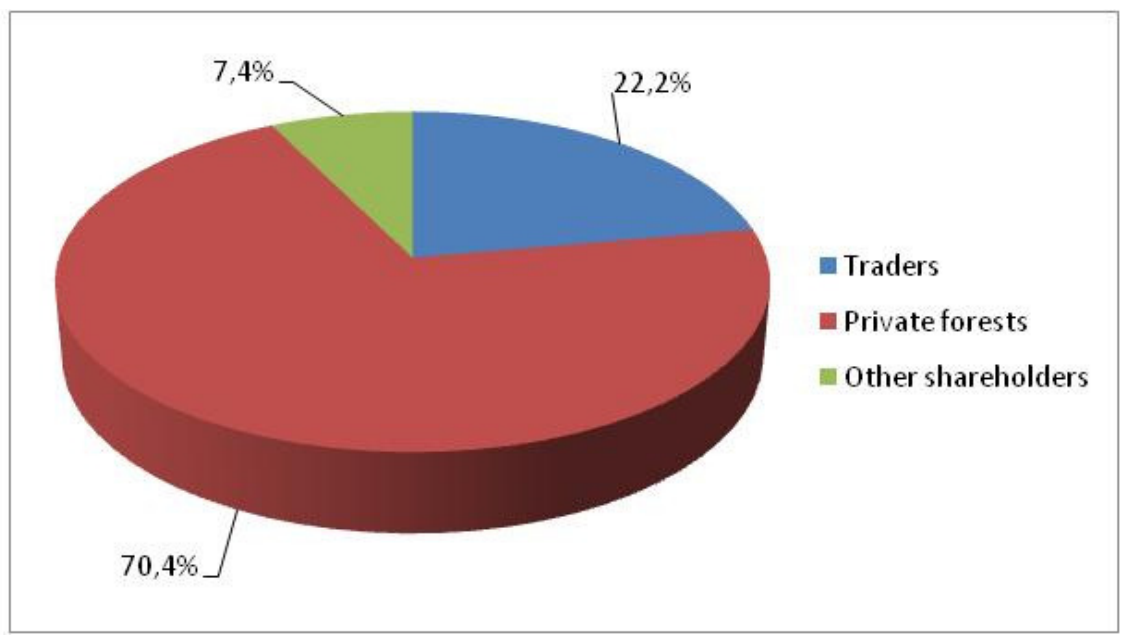

Figure 2. Distribution (in percentage) of sources supplying extra bote rights.

The model used to estimate the forest woody biomass potentiality in the Municipality of Baselga di Pinè evidenced around 2,057 tons of potential biomass (moisture biomass forty percent). This quantity of biomass includes the residues from forest harvesting (top, branches, twigs); these residues may be destined for wood chip. The local market price of wood chip is $€ 75$ per ton, while the price of coniferous firewood (pine and Norway spruce) is around $€ 100$ per ton.

This information, associated with the energy needs of shareholders, allows for the creation of a number of management scenarios (Table 2) useful for the decision makers. The first scenario (economic scenario) assumes that all the potential forest woody biomass and also the firewood actually assigned will be sold on the local market. Taking into consideration this scenario, the potential income for the nine ASUC is, on average, €239,275 per year.

The second scenario (traditional social scenario) assumes that all the potential forest woody biomass will be sold on the local market, and that the quantity of firewood assigned to the shareholders will be the same as in the past (around 850 tons). Should this be the case, the potential income for the nine ASUC will average $€ 154,275$ per year. This will satisfy shareholder demand to the extent of eighteen percent.

In the third scenario, we suppose that the forest residues will be sold on the local market, but that the income would be used to buy firewood to integrate the need of shareholders. In this scenario, the ASUC are oriented towards fulfilling the social function (common property rights satisfaction). Taking into consideration an income of $€ 154,275$ and a price of $€ 100$ per ton for firewood, around 1540 tons per year could be bought. This will satisfy shareholder demand to the extent of fifty-two percent.

\begin{tabular}{|l|l|}
\hline \multicolumn{1}{|c|}{ Scenario } & \multicolumn{1}{c|}{ Scenario description } \\
\hline $\begin{array}{l}\text { Economic } \\
\text { scenario (A) }\end{array}$ & $\begin{array}{l}\text { Optimising the forest woody biomass, and firewood, from an economic point of } \\
\text { view: } \\
\text { Sale of all potential residues (2,057 tons) and of assigned firewood (850 tons) on } \\
\text { the wood chip market. } \\
\text { No shareholder satisfaction. } \\
\text { Potential income: } € 239,275 \text { per year. }\end{array}$ \\
\hline $\begin{array}{l}\text { Traditional } \\
\text { social } \\
\text { scenario (B) }\end{array}$ & $\begin{array}{l}\text { Sale of all potential residues (2,057 tons) on the market. } \\
\text { Maintaining the current amount of firewood in order to satisfy the energy needs } \\
\text { of the householders: around } 850 \text { tons (satisfied around 18\% percent of } \\
\text { householder demand). } \\
\text { Potential income: } € 154,275 \text { per year. }\end{array}$ \\
\hline $\begin{array}{l}\text { Innovative } \\
\text { social }\end{array}$ & $\begin{array}{l}\text { Sale of the potential residues on the market. Purchase of firewood to satisfy } \\
\text { shareholder needs. }\end{array}$ \\
\hline
\end{tabular}


scenario (C) $\quad$ Satisfied around $52 \%$ of householder demand.

Potential income: $€ 0.0$ (zero) per year.

Table 2. Management scenarios.

\section{DISCUSSION}

From the point of view of the community features, the research confirms that the Municipality of Baselga di Pinè still represents a self-governed, self-organised and long-enduring system able to cope with historical, economic, and social troubles. Moreover, nowadays the Baselga Community represents a model of efficiency and good governance, a community characterised by high social capital and a deep connection with local traditions, where social and cultural values are extremely important.

The bote right is perceived by the local community not only in utilitarian terms (supply of firewood at no cost), but also as an ancient tradition capable of strengthening the bond between people and the land. In addition, the current organisation of the ASUC allows ties to be increased between shareholders (network), strengthening the local social capital.

Results show that only a third of the shareholders received an annual share of firewood and that, additionally, whilst around forty-five percent of shareholders are interested in being assigned an annual portion of firewood, they never received any such assignment. These data confirm that the availability of firewood in the municipality is insufficient to satisfy the needs of the total number of shareholders. Information from the survey confirms this trend; around seventy percent of shareholders are not satisfied with their annual share. They supplement their annual quantity with firewood from other shareholders, from private owners, or from local traders.

At the same time, in the area of the municipality we estimated the potential of forest woody biomass to be around 2,000 tons. This biomass includes residues from forest harvesting and could be destined for the production of wood chip.

We can, finally, affirm that the situation in the Baselga Municipality is characterised by a request for firewood and the potential availability of wood chip. In this framework, we defined and compared three scenarios: (1) scenario A - an economic scenario, in which potential biomass and firewood actually assigned are fully sold on the local market. While this scenario is aimed at fulfilling market demand in the sector of renewable bio-energy production by means of forest woody biomass, bote rights are neglected; (2) scenario B - a traditional social scenario. In this case, the objective is to maintain a balance between market demand and the traditional custom of assigning firewood to shareholders; (3) scenario $\mathrm{C}$ - an innovative social scenario in which the income from the sale of woody biomass is destined to satisfy shareholders' need for firewood.

Information derived from these scenarios is important in that it helps managers and decision makers to identify on-going trends in firewood demand and can be efficiently integrated into the strategies of the management and government of natural resources (Burstein, 2003; Page and Shapiro, 1983).

The responses received to the open-ended questions and the notes taken during interviews showed that despite the interviewees' attachment to traditional systems, they are not in principle opposed to alternative uses of wood for the production of energy, and neither are they opposed to a local district heating plant. Having said this, however, there are those who, with the dynamics of the community in mind, maintain that realistically there are no grounds - social more so than technical - for the establishment of such a plant.

In particular, emphasis is placed on the fact that not only is there a lack of collaboration between the various ASUC, but there is also friction between them and the city; the ASUC feel that, of late, they have lost all their decision-making power to the city. This, in turn, casts a long shadow over the future development of the forest-wood-energy chain in the Province of Trento. It is opportune, first of all, to ponder the following considerations:

i) there exists an effective potential on the part of forest ecosystems towards greater production of wood for the purposes of energy use; 
ii) provided it is economically sustainable, a more extensive use of the wood requires suitable technical solutions, such that the difficulties imposed by the mountain environment are able to be overcome;

iii) a significant investment in terms of technology and know-how will only bear fruit provided a suitable plan is put in place and the land chosen sufficiently extensive, and if the forest enterprises concerned can be assured of a suitable, long-term supply of material.

More than implying common intent and collaboration on the part of the ASUC, strict coordination also between the ASUC, the city, and the province is vital.

To-date, development projects concerning the forest-wood-energy chain pursued in the Province of Trento do not appear to have taken into account the complex problems associated with the use of wood for the purposes of energy use.

The production of heat energy by means of wood chip has risen rapidly over the last few years, and a number of district heating plants can be found on land belonging to the province. There are, however, problems with procurement; wood chip has to be bought from other provinces, and often from abroad. It would be opportune to reflect on this lack of autonomy, and a meeting convened between public decision makers and local communities to evaluate, together, the feasibility and eventual realisation of certain projects, in terms of procurement and taking into consideration problems of a technical, economic, as well as a social and cultural nature.

To this end, the development of scenarios such as are described in this paper may reveal itself a useful aid in identifying solutions that also take into account local customs and needs.

\section{CONCLUSION}

Despite the critical situation brought to light by the interviews (De Meo et al., 2012), which can furthermore be found also in other institutions present in Trentino, the community possesses high social capital and may still today be considered a model of governance to be followed.

The great interest shown by the population in the sharing of firewood and their strong attachment to heating systems based on traditional wood use are surely a sign of the very strong bonds between the people and their own territory, and the forest in particular.

At the same time, the potential of, and interest shown towards, woody biomass for energy is evidence that a fruitful discussion regarding the forestry sector may be a good starting point for designing more general hypotheses in the development of the territory. It is to be hoped that these hypotheses will take into consideration also the relaunching of animal husbandry and agricultural activities, and that all this will eventually be done in synergy with forms of tourism that are sustainable and mindful of the environment.

Over the last few years, the rediscovery of collective property and the institutions that govern them has enjoyed a great deal of attention.

In an attempt to find concrete, practicable answers to the contradictions of globalisation, environmental disasters, and the failure of models of development whose origins lie in liberal thinking, the recent economic-financial crisis has in fact given birth to a new and increasing interest in the question of common goods.

In common with other, similar institutions, and not only in Trentino, the ASUC of Baselga find themselves at a crossroads: reinvent themselves or die a slow death. Currently, they are faced with many expectations, which challenges their capacity to adapt, yet again, to the changing times.

If these communities succeed in taking into account possible new functions, widening the circle of interested stakeholders, and maintaining cohesion amongst the population in matters of common interest and values, then they stand a very good chance of overcoming the current crisis, and in so doing become an inspiration for new models of development and conservation of the natural resources present in these territories. 
What is more, this kind of study may well contribute to solving the lack of practical, pragmatic planning tools useful for dissecting the complex interaction that exists between the environmental-, socio-economic-, and political aspects related to the use of this type of bio-fuel.

\section{LITERATURE CITED}

Burstein, P. 2003. "The Impact of Public Opinion on Public Policy: a Review and an Agenda." Political Research Quarterly 56(1): 29-40.

Cocciardi, D. 2011. “Analisi della percezione dei proprietari boschivi in merito all'impiego delle biomasse forestali come fonte di energia rinnovabile. Il caso delle Amministrazioni Separate di Uso Civico di Baselga di Piné.". PhD diss., University of Trento, Italy.

Cole, J.W.; and Wolf, E.R. 1974. The hidden frontier: ecology and ethnicity in an Alpine valley. New York, London, Academic Press.

De Meo, I., and Cantiani, M.G., and Cocciardi D., and Paletto, A. 2012. "Comunità locali e governance del territorio: un'indagine percettiva nell'Altopiano di Pinè.” Dendronatura 33(1): 2640.

INEA, 1947. La distribuzione della proprietà fondiaria in Italia. Istituto Nazionale di Economia Agraria, Roma.

Kissling-Näf, I., and Volkent, T., and Bisang, K. 2001. "Common properties and natural resources in the Alps: the decay of management structures?" Forest Policy and Economics 4: 135-147.

Merlo, M. 1955. "Common property regimes in the forest: just a relic from the past?" Unasylva 46: 58-63.

Messerli, P. 1989. Mensch und Natur im alpinen Lebensraum. Risiken, Chancen, Perspektiven. Stuttgart, Verlag Paul Haupt Bern.

Netting, R., 1981. Balancing on an Alp: ecological change and continuity in a Swiss mountain. Cambridge, Cambridge University Press.

Ostrom, E. 1990. Governing the Commons. The Evolution of Institutions for Collective Action. Cambridge, Cambridge University Press.

Page, B., and Shapiro, R. 1983. "Effects of Public Opinion on Policy." American Political Science Review 77: 175-190.

Sacchelli, S., and De Meo, I., and Paletto, A. 2011. "The analysis of logging residues chain for a sustainable bioenergy production: a case study in Northern Italy." In Efficient and safe production processes in sustainable agriculture and forestry, edited by E. Quendler, K. Kossler. Proceedings of XXXIV CIOSTA Conference, Vienna.

Scotti, R., and Cadoni, M. 2007. "A historical analysis of traditional common forest planning and management in Seneghe, Sardinia. Lessons for sustainable development." Forest Ecology and Management 249: 116-124.

Sereni, E. 1955. Comunità rurali nell'Italia antica. Roma, Edizioni Rinascita. 
Sitzia, T. 2009. Ecologia e gestione dei boschi di neoformazione nel paesaggio trentino. Trento, Provincia Autonoma di Trewnto -

Viazzo, P.P. 1989. Upland communities. Environment, population and social structure in the Alps Since the sixteenth century. Cambridge, Cambridge University Press.

Vigna, A. 1989. Piné...Ieri. Trento, Euroedit.

Wolf, E.R. 1962. "Cultural Dissonance in the Italian Alps.” Comparative Studies in Society and History 5(1): 1-14. 